Ks. Antoni SWOBODA

(Poznań, UAM)

\title{
POSTAWA DZIECKA WOBEC MATKI W OCENIE ŚW. AUGUSTYNA
}

Święty Augustyn (353-430), Biskup Hippony, znany jest przede wszystkim jako wybitny filozof i teolog. Jego dzieła są także dla współczesnych źródłem inspiracji i poszukiwań na tych polach. W swych pismach nie tylko porusza on wielkie tematy teologiczne, ale znaleźć w nich możemy wiele przemyśleń odnoszących się do życia moralnego człowieka. Jest on także duszpasterzem, któremu bardzo zależy na zbawieniu człowieka, któremu adresuje swe przemyślenia ubogacone głęboką refleksją teologiczną. Augustyn, jak pokazują to jego pisma, potrafi zwracać się również do pojedynczych osób udzielając im różnych rad czy też polemizując z ich poglądami.

W jego pismach nie brak również przemyśleń na temat małżeństwa i rodziny. Owocem tych refleksji jest szereg dzieł, w których podejmuje te problemy. Nie są to tylko i wyłącznie dzieła zaliczane do grupy moralno-pastoralnych, gdyż jego przemyślenia na te właśnie tematy, aktualne również w dobie współczesnej, ,rozsiane” są po wszystkich jego pismach.

Stąd, idąc za tą myślą, pragniemy w niniejszym opracowaniu obejmującym tylko bardzo wąski wycinek jego zainteresowań problematyką rodzinną, przybliżyć stanowisko Augustyna na temat postaw dorosłego już dziecka wobec matki. Posługując się metodą analityczno-syntetyczną wybierzemy z pism Biskupa Hippony tylko te, w których pokazuje on i ocenia tego właśnie rodzaju relacje. Innymi słowy, przedmiotem zainteresowania będą tylko te wypowiedzi naszego autora, w których mówiąc na temat matki ukazuje jednocześnie różne postawy dziecka wobec swej rodzicielki. Analiza zachowanych pism naszego autora pokazuje, że do dzieł tych zaliczyć można nie tylko Confessiones ${ }^{1}$, w których znajdujemy najwięcej przykładów dotyczących interesującego nas tematu, ale także to zagadnienie przewija się w takich pismach jak: De beata vita ${ }^{2}$, De bono coniu-

${ }^{1}$ Por. Confessiones, ed. J.P. Migne, PL 32, 659-868; ed. P. Knöll, CSEL 33; ed. L. Verheijen, CCL 27; przekład polski: Z. Kubiak, Wyznania, Warszawa 1999.

${ }^{2}$ Por. De beata vita, PL 32, 959-976; ed. W.M. Green, CCL 29, 65-85; przekład polski: A. Świderkówna, O życiu szczęśliwym, w: Dialogi filozoficzne, I, Warszawa 1953, 5-42. 
gali $^{3}$, De bono viduitatis ${ }^{4}$, De civitate $\mathrm{Dei}^{5}$, De ordine ${ }^{6}$, Epistolae ${ }^{7}$, In Joannis Evangelium tractatus ${ }^{8}$, Opus imperfectum contra secundam responsionem Julia$n i^{9}$, Quaestiones in Heptateuchum ${ }^{10}$, Sermones ${ }^{11}$.

Opracowanie składać się będzie z czterech zasadniczych części. W pierwszej części ukazany zostanie pogląd Augustyna na miejsce matki w życiu człowieka. W drugiej przybliżymy wizerunek matki w ocenie dorosłego dziecka. Trzecia część omawiać będzie różne zachowanie dziecka wobec żyjącej matki. Ostatnia zaś pokaże postawę dorosłego dziecka w obliczu śmierci matki. Zakończeniem pracy będą stosowne wnioski.

\section{MIEJSCE MATKI W ŻYCIU CZŁOWIEKA}

Podejmując się ukazania oceny postaw dziecka wobec matki w świetle pism św. Augustyna, a zwłaszcza pragnąc przedstawić opinię Biskupa Hippony na temat miejsca matki w życiu człowieka, musimy zauważyć, iż nasz autor kierował się tutaj jasno sprecyzowaną hierarchią wartości. Potwierdza to wypowiedź zawarta w jednym z jego listów, w której adresatowi przypomina, że miłość do matki czy ojca nie może przysłaniać miłości do Boga ${ }^{12}$. Tę myśl umieszcza

${ }^{3}$ Por. De bono coniugali, PL 40, 373-396; ed. J. Zycha, CSEL 41, 187-230, przekład polski: W. Eborowicz, Wartości matzeństwa, w: Pisma św. Augustyna o matzeństwie i dziewictwie, red. A. Eckmann, Lublin 2003, 73-116.

${ }^{4}$ Por. De bono viduitatis, PL 40, 429-450; ed. J. Zycha, CSEL 41, 305-343, przekład polski: T. Gacia, $O$ doskonatym wdowieństwie, w: Pisma św. Augustyna o matzeństwie i dziewictwie, red. A. Eckmann, Lublin 2003, 183-222.

${ }^{5}$ Por. De civitate Dei, PL 41, 13-804; Ed. B. Dombart - A. Halls, CCL 47-48; Ed. E. Hoffmann, CSEL 40/1-2, przekład polski: W. Kornatowski, O państwie Bożym, I-II, Warszawa 1977.

6 Por. De ordine, PL 32, 977-1020; ed. P. Knöll, CSEL 63, 121-185; ed. W.M. Green, CCL 29, 89-137; przekład polski: J. Modrzejewski, O porządku, w: Dialogi filozoficzne, I, Warszawa 1953, 146-226.

7 Por. Epistolae, PL 33, 61-1094; ed. A. Goldbacher, CSEL 34, 44, 57, 58; ed. J. Divjak, CSEL 88, przekład polski: W. Eborowicz, Listy (1-75), Pelplin 1991. Pozostałe listy cytuję w przekładzie własnym.

${ }^{8}$ Por. In Joannis Evangelium. tractatus CXXIV, PL 35, 1389-1976; ed. R. Willems, CCL 36; przekład polski: W. Szołdrski, Homilie na Ewangelie św. Jana, PSP 40/ 1-2, Warszawa 1977.

9 Por. Opus imperfectum contra secundam responsionem Juliani, PL 45, 1049-1608; ed. E. Kalinka - M. Zelzer, CSEL 85/1, 3-506.

${ }^{10}$ Por. Quaestiones in Heptateuchum libri VII, PL 34, 547-824; ed. J. Zycha, CSEL 28/2; ed. J. Fraipont, CCL 33, 1-377, przekład polski: J. Sulowski, Problemy Heptateuchu, PSP 46-47, Warszawa 1990.

11 Por. Sermones, PL 38-39, 23-1638, przekład polski: J. Jaworski, Wybór mów: kazania świateczne i okolicznościowe, PSP 12, Warszawa 1973. Mowy znajdujące się poza tym zbiorem cytuję w przekładzie własnym.

12 Por. Epistola 243, 9, PL 33, 1058. W Sermo 349, 4 (PL 39, 1531), rozróżnia trzy rodzaje miłości: dozwolona miłość ludzka (licita humana), niedozwolona miłość ludzka (illicita humana) oraz wzniosła i boska (excellens atque divina). 
również w jednej ze swych mów, w której konstatuje, że miłość do rodziców, żony i dzieci nie może przysłaniać miłości do Boga. Nasz autor, który, jak to zauważa G. Bardy ${ }^{13}$, kochał swą matkę, a od chwili nawrócenia i chrztu czuł się jej bliższy niż kiedykolwiek, jest przekonany, że:

„należy kochać ojca, ale nie więcej niż Boga, kochać należy rodzica, ale nie bardziej niż Stwórcę gdyż ojciec ziemski zrodził, ale nie ukształtował człowieka, ponieważ nie wiedział, kogo rodzi, karmił, ale sam nie przygotował chleba pragnącemu. Dopiero po jego śmierci dzieci odziedziczą to, co zgromadzil"14.

Tak samo też, jego zdaniem, ,kochać należy matkę, ale nie bardziej niż Kościół, który zrodził człowieka do życia wiecznego"15. Wypowiadając te słowa Biskup Hippony jest przekonany, że ,z miłości samych rodziców” winno się wiedzieć, jak należy kochać Boga i Kościół. Pogłębiając tę myśl Augustyn podkreśla, że:

„jeśli należy kochać rodziców, to tym bardziej należy kochać tych co zrodzili do życia wiecznego"16.

Również mąż i ojciec, jak czytamy dalej, powinien otaczać miłością swą żonę i dzieci, kochać ich jednak po Bożemu (secundum Deum), by one razem z nim czciły Boga. Nie może on jednak, jak wyraźnie zaznacza nasz autor, kochać ich bardziej niż Boga. Innymi słowy, dla Augustyna miłość męża do żony i ojca do dzieci, a także dzieci do rodziców, która nie prowadzi ich razem do Boga, jest złą miłością ${ }^{17}$.

Dla Biskupa Hippony, przedstawiona hierarchia wartości nie ulega zachwianiu nawet w momentach trudnych, jakimi są prześladowania. Augustyn jest świadom, że w takich chwilach ojciec, żona lub dziecko będą czynić wszystko, by nikt z nich nie zginął. Nie zmienia to jednak faktu, że w tych okolicznościach, miłości do bliskich nie należy przedkładać nad miłość do Boga ${ }^{18}$.

Lektura wypowiedzi Augustyna pozwala nam również zauważyć, że ta sama hierarchia wartości obowiązuje także tych, którzy pragną poświęcić się służbie Bożej. Przypomniał to w swym liście do Letusa, w którym czynił mu wyrzuty za to, że jest on zaprzątnięty domowymi troskami i ociąga się w służbie Bogu ${ }^{19}$.

13 Por. Święty Augustyn. Człowiek i dzieło, tłum. Z. Kobylańska, Warszawa 1955, 120.

14 Sermo 344, 2, PL 39, 1512.

${ }^{15}$ Por. tamże. W tym miejscu podzielamy opinię Ch.N. Cochrane (Chrześcijaństwo i kultura antyczna, tłum. G. Pianko, Warszawa 1960, 372), który uważa, że Augustyn nie jest ofiarą schorzałej duszy, znajdującej w swym oddaniu matce-Kościołowi kompensatę za chorobliwą namiętność dla pamięci swej matki Moniki.

${ }^{16}$ Sermo 344, 2, PL 39, 1512: ,[...] ex ipsorum parentum amore [...]”.

17 Por. tamze: „Ideo non debes illos plus Deo diligere, quos omnino male diligis, si neglexeris tecum ad Deum ducere".

18 Por. tamże.

19 Por. Epistola 243, 11, PL 33, 1059. 
W wyborze tej drogi nie powinny go nawet, zdaniem naszego autora, martwić łzy matki. Jeśli bowiem jest w nim uporządkowana miłość (caritas ordinata), to winien on przedkładać rzeczy ważniejsze nad mniej ważne (praeponere maiora minoribus) po to, by poruszony miłosierdziem, niósł ubogim ewangelię wypełniając wolę Bożą ${ }^{20}$.

Powyższe wypowiedzi Augustyna, ukazujące tak rozumianą hierarchę wartości, nasuwają pytanie o to, czym uzasadniał on taki, a nie inny porządek rzeczy, zwłaszcza w kontekście wypowiedzi na temat relacji między dzieckiem a matką. Z lektury jego pism wynika wyraźnie, że swe stanowisko starał się potwierdzić nauką płynącą z Pisma św. Innymi słowy, wybór takiej hierarchii wartości dostrzegał w postawie samego Chrystusa, który wskazując na swych uczniów stwierdził, że jego matką są ci, którzy pełnią wolę Bożą ${ }^{21}$. Opierając się z kolei na Mt 10, 37-38 zauważył, że miłość do rodziców, żony i dzieci nie może przysłaniać miłości do Boga. Chrystus bowiem, jak czytamy dalej, nie zniósł tej miłości, ale ją uporządkował ${ }^{22}$, On sam jest również wzorem miłości do rodzi$\mathrm{ców}^{23}$. Biorąc powyższe pod uwagę, Augustyn w liście do wspomnianego już Letusa, któremu w poświęceniu się służbie Bożej sprzeciwiała się jego matka, zachęca go, by poniósł swój krzyż i podążał za Panem, by ten krzyż ukrzyżował i przybił gwoździami bojaźni Bożej, by go mógł nieść spoczywającego na swych uwolnionych i swobodnych już barkach. „Nie można bowiem iść za Panem, gdy nie niesie się tego krzyża i nie należy do Niego" ${ }^{24}$.

\section{MATKA W OCENIE DZIECKA}

Analiza wypowiedzi Augustyna pod kątem obranego przez nas tematu, przynosi szereg spostrzeżeń autora, dotyczących cech matki. Biskup Hippony, jak wykaże to analiza jego wypowiedzi, nie ogranicza się tylko do ich wyliczenia, ale przede wszystkim jako filozof, teolog i duszpasterz stara się pogłębić to interesujące go zagadnienie.

1. Bogactwo cnót. Lektura pism Augustyna, będących przedmiotem naszego zainteresowania, pozwala zauważyć, że ich autor kierował pod adresem, zwłaszcza swej matki, słowa pochwały ${ }^{25}$ ukazując jej przymioty umysłu, który

20 Por. Epistola 243, 12, PL 33, 1059: „Si est in te caritas ordinate, scias praeponere maiora minoribus".

21 Por. Epistola 243, 9, PL 33, 1058; por. Mt 12, 48-50.

22 Por. Sermo 344, 2, PL 39, 1512.

23 Por. In Joannis Evangelium tractatus 119, 2, PL 35, 1951; zob. L. Cignelli, La „Famiglia modello” nella Chiesa patristica, „Liber Annus” 32 (1982) 182.

${ }^{24}$ Por. Epistola 243, 11, PL 33, 1059; zob. Mt 16, 24; Mk 8, 34; Łk 9, 23; Ps 118 [119], 120; Gal 5, 24 .

25 Por. De ordine I 11, 32, PL 32, 994; I 11, 33, PL 32, 994; II 17, 45, PL 32, 1016. 
„każdego dnia objawia się, jak pisze, tak samo świeży”, a także charakteru, pełnego umiarkowania i ducha wolnego od cielesnej skazy ${ }^{26}$. Innymi słowy, możemy powiedzieć, że nasz autor oceniając jako syn swą matkę, zwraca przede wszystkim uwagę na jej cnoty $^{27}$, zwłaszcza męstwo w pokonywaniu trudności i niebezpieczeństw ${ }^{28}$, przede wszystkim jednak na cnotę miłości, którą również obdarzona była jego matka, a której wyrazem były słowa pociechy wypowiadane pod adresem syna ${ }^{29}$, jej szacunek i oddanie dla dziecka ${ }^{30}$, troska o jego nawrócenie ${ }^{31}$, obecność przy dziecku ${ }^{32}$, macierzyńska bezpośredniość ${ }^{33}$ czy też, jak zauważa to J. Jundziłł ${ }^{34}$, cierpliwość i pokora ${ }^{35}$. Matkę Augustyna cechowała też wielka skromnośćc ${ }^{36}$ i posłuszeństwo rozporządzeniom biskupa Mediolanu ${ }^{37}$, który także wysoko oceniał i pochwalał Monikę gratulując Augustynowi takiej matki ${ }^{38}$.

2. Przymioty umysłu. Biskup Hippony wypowiadając się na temat swej matki zauważa również, że źle oceniłby ją, gdyby nie kochała ona mądrości, ale też nie potępiłby jej, gdyby tę mądrość choć trochę kochała tak, jak on sam ją kocha" ${ }^{39}$. Z dalszych wypowiedzi naszego autora wynika, że jego matce nie sprawiało trudności zgłębianie i poznawanie wielu skomplikowanych zagadnień filozoficznych czy teologicznych ${ }^{40}$, znała ona również, jak podkreśla, istotę gramatyki ${ }^{41}$ oraz pisma współczesnych sobie i dawnych autorów ${ }^{42}$. Stąd też,

${ }^{26}$ Por. tamże II 17, 45, PL 32, 1015-1016:, ,[...] cujus ingenium quotidie mihi novum est [...] animum vel aetate vel admirabili temperantia remotissimum ab omnibus nugis, et a magna labe corporis emergentem [...]”; zob. Bardy, Święty Augustyn, s. 106.

27 Por. Confessiones IX 12, 29, PL 32, 776; zob. S. Kowalczyk, Człowiek i Bóg w nauce św. Augustyna, Warszawa 1987, 86; P. Nehring, Wstęp, w: Święty Augustyn, Pisma monastyczne, ŹM 27, Kraków 2002, 42.

${ }^{28}$ Por. Confessiones IX 11, 27, PL 32, 755; zob. Bardy, Święty Augustyn, s. 119; J. Jundziłł, Ideat zony i matki w „Wyznaniach” św. Augustyna a klasyczne wzorce rzymskie, VoxP 15 (1988) 821.

${ }^{29}$ Por. Confessiones IX 12, 30, PL 32, 776.

${ }^{30}$ Por. tamze IX 12, 30, PL 32, 776.

${ }^{31}$ Por. tamze IX 12, 30, PL 32, 776.

32 Por. Epistola 54, 1-3, PL 33, 200.

33 Por. Confessiones IX 11, 28, PL 32, 775: „materna fiducia”.

34 Por. Jundziłł, Ideał żony i matki, s. 822.

35 Por. Confessiones IX 13, 34, PL 32, 778.

36 Por. tamże IX 13, 34, PL 32, 778; zob. Bardy, Święty Augustyn, s. 106.

${ }^{37}$ Por. Confessiones 6, 2, PL 32, 720; Epistolae 36, 14, 32, PL 33, 151; 54, 1, 2, 3, PL 33, 200; zob. A. Trapè, Swięty Augustyn. Człowiek - duszpasterz - mistyk, tłum. J. Sulowski, Warszawa 1987, 27.

38 Por. Confessiones VI 1, 1, PL 32, 718-719; zob. Trapè, Święty Augustyn, s. 72

39 Por. De ordine I 11, 32, PL 32, 994.

40 Por. tamże II 17, 45, PL 32, 1016.

${ }^{41}$ Por tamże II 17, 45, PL 32, 1016. Trudno więc zgodzić się do końca z opinią F.E. Consolino (Modelli di santità feminile nelle più antiche Passioni romane, „Augustinianum” 24:1984, 107) według którego Monika nie miała wykształcenia.

42 Por. De ordine I 11, 31, PL 32, 993. 
w jego przekonaniu, jego matka, wzorem starożytnych kobiet interesujących się filozofią, zdolna jest do oddania się tego rodzaju studiom ${ }^{43}$, gdyż kocha ona mądrość bardziej niż syna i osiągnęła ideał wymarzony przez mędrców, ponieważ nie lękała się zła ani śmierci ${ }^{44}$.

Cechą pozytywną matki Augustyna, jak zauważa to w swym studium G. Bardy, jest także jej zdolność nie tylko do udzielania mądrych rad synowi ${ }^{45}$, ale także twórczy udział w prowadzonych dyskusjach także poprzez umiejętne stawianie pytań ${ }^{46}$. Nic więc dziwnego, ze ich uczestnicy, jak potwierdza to także Augustyn, cieszyli się z jej obecności, gdyż jej uwagi wnosiły element zdrowego rozsądku i pobożności chrześcijańskiej, co tym dyskusjom nadawało właściwy sens ${ }^{47}$.

3. Wysoka moralność. Analiza wypowiedzi Augustyna pozwala również zauważyć, iż ich autor pochwalał wysoką moralność swej matki, czego przykładem był, jego zdaniem, fakt, iż od czasu, kiedy przyjęła chrzest, z jej ust nie padło żadne sprzeczne z przykazaniami Bożymi słowo. Jej obyczaje, wyrazem których były dobre uczynki, okazywanie przebaczenia i miłosierdzia innym oraz niewinność, jak stwierdza, pobudzały innych do chwalenia Boga ${ }^{48}$.

4. Glęboka wiara. Moralność ta, naszym zdaniem, nie tyle była owocem wiedzy, ale przede wszystkim wiary i głębokiej religijności. Przekonuje o tym studium wypowiedzi św. Augustyna, który w swej charakterystyce pozytywnych cech matki nie pominął tego zagadnienia. Biskup Hippony pochwalał więc gorliwą wiarę matki ${ }^{49} \mathrm{i}$ oddanie $\mathrm{Bogu}^{50}$, czego wyrazem były, między innymi, praktykowane posty, cześć dla męczenników, a przede wszystkim pobożność ${ }^{51}$, zwłaszcza eucharystyczna ${ }^{52}$, wyrażająca się w głębokiej modlitwie $e^{53}$

43 Por. tamże I 11, 31, PL 32, 993; zob. Bardy, Święty Augustyn, s. 105.

44 Por. De ordine I 11, 32, PL 32, 994: ,[...] eam multo plus quam meipsum diligas [...]”.

45 Por. Bardy, Święty Augustyn, s. 38.

46 Por. De beata vita I 2, 16, PL 32, 967; zob. Bardy, Święty Augustyn, s. 105.

47 Por. De ordine I 11, 31, PL 32, 993; zob. Bardy, Święty Augustyn, s. 105.

48 Por. Confessiones IX 13, 34, PL 32, 778: ,,[... sic vixerit ut laudetur nomen tuum in fide moribusque ejus $[\ldots]$ ".

${ }^{49}$ Por. tamże IX 11, 28, PL 32, 776; zob. A. Młotek, Postawy i świadectwa. Kościót wobec problemów moralnych IV wieku, Wrocław 1986, 42; Bardy, Swięty Augustyn, s. 105; Kowalczyk, Człowiek i Bóg w nauce św. Augustyna, s. 86.

${ }^{50}$ Por. Confessiones IX 12, 33, PL 32, 777.

${ }^{51}$ Por. tamże I 11, 17, PL 32, 669; VI 1, 1, PL 32, 718-719. Z kolei w Epistola 212 (PL 33, 965) Augustyn poleca opiece Kwintyliana i pochwala wdowę i matkę Gallę oraz jej córkę Siplicjolę, które określa pojęciem czcigodnych służebnic Pańskich (honorabiles Dei famulas) i drogocennymi członkami Chrystusa (pretiosa Christi membra), które postanowiły sprowadzić relikwie św. Stefana męczennika; zob. Trapè, Święty Augustyn, s. 72.

52 Por. Confessiones IX 13, 36, PL 32, 778.

53 Por. tamże III 11-12, PL 32, 691-694; zob. Trapè, Święty Augustyn, s. 27. 
dzięki której, jak stwierdza, „Bóg nasunął mu myśl, by nie starał się o nic bardziej i niczego bardziej nie pożądał, i o niczym bardziej nie myślał i pragnął, jak tylko wykrycia prawdy”. Osobiście wierzył, że „dzięki tym modlitwom on i jego przyjaciele osiągną dobro, którego pożądać pozwoliły im jej zasługi" ${ }^{4}$. Ta modlitwa, zwłaszcza pod koniec jej życia, ubogacona była, jak wynika to z relacji Augustyna, przeżyciami mistycznymi ${ }^{55}$.

Jej wiara, jak zauważa to z kolei J. Jundziłł, choć niedoskonała, ulegała metamorfozie pod wpływem rozumnego kierownictwa, zwłaszcza biskupa Mediolanu, Ambrożego. Matka Augustyna w swej wierze była tak stanowcza, że, jak zauważa to Jundziłł, całą rodzinę, nie przez wymuszanie i presję, ale cierpliwością i wyszukiwaniem sprzyjających okazji, wspartych usilną modlitwą i pokorą wobec wyroków Boskich doprowadziła do Boga ${ }^{56}$ i Kościoła ${ }^{57}$. Za F.E. Consolino możemy więc powiedzieć, że Augustyn przedstawiał i charakteryzował swą matkę jako osobę świętą ${ }^{58}$ nie tylko w wymiarze doczesnym, ale również, naszym zdaniem, w wymiarze eschatologicznym, co potwierdza Augustyn, kiedy pisze o wierze swej matki w przyszłe zmartwychwstanie ${ }^{59}$.

\section{ZACHOWANIE DZIECKA WOBEC ŻYJACEJ MATKI}

Analiza pism św. Augustyna, będących przedmiotem naszego studium, przynosi nam również szereg informacji odnoszących się do zachowań syna wobec żyjącej matki. Spotykamy się tu z postawami nagannymi, jak i zachowaniami pozytywnymi. Przykłady takich właśnie postaw postaramy się w tym miejscu przybliżyć.

1. Postawy negatywne. Lektura pism Biskupa Hippony, będących przedmiotem naszego zainteresowania, pozwala zauważyć, że do negatywnych postaw syna wobec matki nasz autor zalicza, między innymi, obojętność dziecka wobec jej cierpień czy doznawanych zniewag. Potwierdza to, znajdujące się

${ }^{54}$ De ordine II 20, 52, PL 32, 1020: „Quae vota ut devotissime impleantur, tibi maxime hoc negotium, mater, injungimus; cujus precibus indubitanter credo atque confirmo mihi istam mentem Deum dedisse, ut inveniendae veritati nihil omnino praeponam, nihil aliud velim, nihil cogitem, nihil amem"; por. Bardy, Swięty Augustyn, s. 106.

55 Por. Confessiones IX 10, 23-26, PL 32, 774-775; zob. Kowalczyk, Człowiek i Bóg w nauce św. Augustyna, s. 230.

56 Por. Jundziłł, Ideat żony i matki, s. 822.

57 Por. Confessiones VI 1, 1, PL 32, 718-719; II 2, PL 32, 720; IX 11, 28, PL 32, 775-776; IX 12, 33, PL 32, 777; zob. Jundziłł, Ideał żony i matki, s. 821.

58 Por. Consolino, Modelli di santità feminile, s. 107. Naszym zdaniem, trudno pogodzić się ze stwierdzeniem autora, z którego wynika, że matka Augustyna nie miała, jak stwierdza, ewidentnego heroizmu wymaganego od męczenników.

59 Por. Confessiones IX 11, 28, PL 32, 776. 
wśród mów Augustyna, pismo skierowane do, jak czytamy, ,papa Augustine” przez pewnego Pawła, który opisuje sytuację zaistniałą w rodzinie zamieszkującej w Cezarei Kapadockiej. Z pisma tego wynika, że jeden z synów znieważył swą matkę, świadkowie zaś tego zdarzenia byli obojętni do tego stopnia, że nie spytali się nawet dlaczego to uczynif ${ }^{60}$.

$\mathrm{Z}$ oceną negatywną, tym razem ze strony Augustyna, spotkała się też postawa niewdzięczności syna wobec matki ${ }^{61}$. Osobiście w swych Confessiones przyznaje, że sam nie zawsze, zwłaszcza w młodości, stosował się do jej rad. Upomnienia, by nie uległ grzechowi cudzołóstwa i by nie uwiódł cudzej żony, uważał za „babskie gadanie” godne odrzucenia i nie warte wprowadzenia w życie ${ }^{62}$. Przyznaje, że jako dziecko złościł się na swych rodziców za to, że nie spełniają wszystkich jego zachcianek ${ }^{63}$.

W niektórych wypowiedziach Augustyna pod adresem swej matki, co naszym zdaniem, nie świadczy jeszcze o jego postawie zdecydowanie negatywnej, znajdujemy również słowa pewnego rodzaju wyrzutu, że przyczyniła się ona do opóźnienia jego chrztu ${ }^{64}$, a także nie zawsze wychowywała go do koniecznej stanowczości oraz to, że nie zabezpieczyła jego czystości tak zdecydowanie, jak go do niej nakłaniała oddalając zawarcie małżeństwa ${ }^{65}$.

Zdecydowanie natomiast negatywną postawę wobec matki osądza Augustyn we wspomnianym wyżej liście adresowanym do Euzebiusza, w którym wspomina o pewnym młodzieńcu, który groził swej matce ${ }^{66}$, prześladował ją, a nawet bił i maltretowal ${ }^{67}$. W tym samym duchu wypowiedzianą ocenę znajdujemy także w jednej z jego mów, gdzie informuje o pewnym młodym człowieku, który w sposób straszliwy znieważył swą matkę oraz pobif ${ }^{68}$. Stąd też w kolejnym liście pisanym do Euzebiusza potępia, podobnie jak czyni to adresat, zbrodnicze postępowanie syna wobec matki ${ }^{69}$, którego w poprzednim liście za to, że pragnął ją zabić ${ }^{70}$, określa jako matkobójcą ${ }^{71}$ i gani jego występne postępowanie $^{72}$.

${ }^{60}$ Por. Sermo 322, PL 38, 1443.

61 Por. Epistola 34, 2-3, PL 33, 132.

62 Por. Confessiones II 3, 7, PL 32, 678: „Qui mihi monitus muliebres videbantur, quibus obtemperare erubescerem"; zob. Bardy, Swięty Augustyn, s. 38.

${ }^{63}$ Por. Confessiones I 7, 11, PL 32, 665.

64 Por. tamże I 11, 18, PL 32, 679; zob. Trapè, Święty Augustyn, s. 27.

65 Por. Confessiones II 3, 8, PL 32, 678; zob. Trapè, Święty Augustyn, s. 27 i 104; P. Blomenkamp, Erziehung, RACh VI 528.

${ }^{66}$ Por. Epistola 34, 2, PL 33, 132: „Minatur eidem matri [...]”.

67 Por. tamże 34, 2-3, PL 33, 132.

68 Por. Sermo 322, PL 38, 1443.

69 Por. Epistola 35, 1, PL 33, 134

${ }^{70}$ Por. tamże 34, 2-3, PL 33, 132: ,,[... matricidii meditator [...]”.

71 Por. tamże 34, 2-3, PL 33, 132.

72 Por. tamże 34, 4, PL 33, 133. 
Do negatywnych zachowań syna wobec matki zalicza Augustyn także współżycie z matką i przypomina, że tego rodzaju czyn został już zabroniony przez Boga ${ }^{73}$. Tę myśl uzupełnia, naszym zdaniem, opinia, według której czymś gorszym jest obcowanie z matką niż z cudzą żoną ${ }^{74}$.

2. Pozytywny stosunek do matki. Biskup z Hippony w swych pismach nie tylko zwracał uwagę i negatywnie osądzał złe zachowania dziecka wobec matki, ale przede wszystkim starał się pokazać postawy pozytywne, godne naśladowania nie tylko, naszym zdaniem, w czasach jemu współczesnych. Do takich należy niewątpliwie wspólne zamieszkiwanie dzieci z matką.

a) Wspólnota z matką. Przykładem jest tutaj sam Augustyn, który po swym nawróceniu zamieszkał w towarzystwie matki i gronie przyjaciół w Cassiciacum, gdzie wszyscy prowadzili, jak zauważa to W. Kornatowski, na wpół zakonny tryb życia ${ }^{75}$. Z perspektywy lat, pisząc swoje Confessiones, Augustyn zauważa, że jego żal po śmierci matki, z którą był mocno związany ${ }^{76}$, mógł być odczytywany jako ziemskie do niej przywiązanie ${ }^{77}$. Przyznaje jednak w formie pytania, że jej śmierć rozerwała „najsłodszą i najdroższą wspólnotę życia z nią," ${ }^{\text {, }}$, która to wspólnota miała przede wszystkim charakter duchowy i budowana była na wzajemnej czci i szacunku, zwłaszcza w wieku dojrzałym autora ${ }^{79}$. Matka bowiem Augustyna, jak zauważa to z kolei Bardy, zajmowała w jego życiu ważne miejsce, a od chwili nawrócenia i chrztu czuł się jej bliski bardziej niż kiedykolwiek $^{80}$. Nie tylko sam Augustyn, ale i jego przyjaciele cieszyli się

73 Por. Quaestiones in Heptateuchum III 58, PL 34, 704, PSP 46, 230; zob. też Kpł 18, 7-8.

74 Por. De bono coniugali 8, 8, PL 40, 379: „[...] peius est enim cum matre quam cum aliena uxore concumbere [...]"; zob. Ef 5, 12.

${ }^{75}$ Por. W. Kornatowski, Społeczno-polityczna myśl św. Augustyna, Warszawa 1965, 113; A.G. Hamman, Życie codzienne w Afryce Pótnocnej w czasach św. Augustyna, thum. M. StafiejWróblewska - A. Sieradzińska, Warszawa 1989, 290. Possydiusz z Kalamy, biograf św. Augustyna w swym dziele Vita Sancti Augustini (26, 1, PL 32, 55, tłum. P. Nehring: Possydiusz z Kalamy, Żywot św. Augustyna, ŹM 26, Kraków -Tyniec 2002, 100) zauważa, że w jego domu, a ma na myśli okres działalności duszpasterskiej Biskupa Hippony, nigdy nie mieszkała żadna kobieta, ani też dłużej tam nie przebywała nawet jego rodzona siostra, ani też córka jego brata, które służyły Bogu, a dla których synody biskupów czyniły wyjątki. Possydiusz ma tu na myśli 17 kanon III synodu w Kartaginie (r. 397), który zezwalał na wspólne zamieszkiwanie w domu duchownych ich matek, babek, ciotek, sióstr oraz córek braci i sióstr.

76 Por. Nehring, Wstęp, s. 42.

77 Por. Confessiones IX 13, 34, PL 32, 778: ,[... iam sanato corde ab illo vulnere in quo poterat redargui carnalis affectus [...]".

${ }^{78}$ Tamże IX 12, 30, PL 32, 776: „Quid ergo erat quod intus mihi graviter dolebat, nisi ex consuetudine simul vivendi dulcissima et charissima repente disrupta vulnus recens?", tłum. Z. Kubiak: Św. Augustyn, Wyznania, Kraków 1999, 254.

79 Por. Jundziłł, Ideat zony i matki, s. 822.

${ }^{80}$ Por. Bardy, Święty Augustyn, s. 120. 
obecnością wśród nich jego matki, która potrafiła to we właściwy sobie sposób docenic ${ }^{81}$.

Ta troska o kontynuowanie takiej wspólnoty uwidacznia się także, naszym zdaniem, w liście do przyjaciela Nebrydiusza, w którym Biskup Hippony wyraża przekonanie, że brat Nebrydiusza, Wiktor, nie opuści swej matki ${ }^{82}$. Jednak ta obecność syna przy matce, jak to wynika z kolejnej wypowiedzi Augustyna, musi być właściwie rozumiana. Nie może być ona wyżej stawiana niż wartości nadrzędne, jakimi są prawda i mądrość. Potwierdza to wypowiedź, którą znajdujemy w Confessiones, gdzie Biskup Hippony wspomina o Nebrydiuszu, który opuścił swe rodzinne miasto, zostawił dom i majątek rodzinny oraz swą matkę, która chciała mu towarzyszyć i udał się razem z nim do Mediolanu w poszukiwaniu, jak czytamy, prawdy i mądrości ${ }^{83}$. Zestawiając tę wypowiedź z cytowanym listem do przyjaciela, który, jak czytamy „wie lepiej, co należy zrobić z matką" ${ }^{84}$, dostrzegamy wyraźnie sens całego kontekstu. Innymi słowy, Augustyn kładzie tutaj przede wszystkim nacisk na przestrzeganie hierarchii wartości, której również podlegać winny relacje między dzieckiem a rodzicem, co potwierdza także uwaga adresowana do Letusa, w której, kierując się wyznawaną przez siebie hierarchią wartości, przypomina, że nawet łzy matki nie powinny go powstrzymywać od poświęcenia się służbie Bogu ${ }^{85}$ i uzasadnia to koniecznością wyboru większej wartości, jaką jest pragnienie ewangelizacji ${ }^{86}$. Ze swej strony, Biskup Hippony ma również świadomość, że przynajmniej częściowo spełnił życzenie swych rodziców, przede wszystkim matki, gdy będąc w Mediolanie słuchaczem biskupa Ambrożego, postanowił zostać katechumenem Kościoła katolickiego ${ }^{87}$.

b). Troska o matkę. Lektura pism Augustyna przynosi szereg przykładów, w których widoczne jest zatroskanie autora nie tylko o swoją matkę. Potwierdza to jego list adresowany do Kwintyliana, w którym poleca jego opiece

${ }^{81}$ Por. De ordine I 11, 31, PL 32, 993; zob. Bardy, Swięty Augustyn, s. 105.

82 Por. Epistola 10, 3, PL 33, 74: „Quid enim cum matre agendum sit, quam certe frater Victor non deserit, tu multo melius calles quam ego".

${ }^{83}$ Por. Confessiones VI 10, 17, PL 32, 728: „Nebridius etiam qui relicta patria vicina Carthagini, atque ipsa Carthagine ubi frequentissimus erat, relicto rure paterno optimo, relicta domo et non secutura matre, nullam ob aliam causam Mediolanum venerat, nisi ut mecum viveret in flagrantissimo studio veritatis atque sapientiae $[\ldots]$ ".

${ }^{84}$ Por. Epistola 10, 3, PL 33, 74: ,[...] tu multo melius calles quam ego”.

85 Por. Epistola 243, 12, PL 33, 1059: ,,[...] quid tibi nocent, aut quo pacto te pervellunt matris lacrymae fluentes $[\ldots] "$.

${ }^{86}$ Por. tamże 243, 12, PL 33, 1059: „Si est in te caritas ordinata, scias praeponere majora minoribus, et misericordia moveri, ut pauperes evangelizentur [...]”. W związku z tym nasuwa się pytanie, czy rzeczywiście Nebrydiusz nie miał prawa opuszczać swej matki, dla której był moralną podporą, jak to sugeruje G. Bardy (Święty Augustyn, s. 127.).

87 Por. Confessiones V 14, 25, PL 32, 717: ,Statui ergo tamdiu esse catechumenus in catholica Ecclesia mihi a parentibus commendata, donec aliquid certi eluceret quo cursum dirigerem". 
wdowę i matkę Gallę ${ }^{88}$, czy też do wspomnianego Letusa pragnącego wybrać stan duchowny, któremu radzi, by swój majątek przekazał matce i domownikom zapewniając $w$ ten sposób ich byt doczesny ${ }^{89}$. Ze swej strony, jak przekonują o tym jego Wyznania, sam temu dawał przykład opiekując się swą matką, zwłaszcza pod koniec jej życia świadcząc jej różnego rodzaju pomoc ${ }^{90}$.

Wyrazem troski o matkę jest też umiejętne dostrzeganie jej trudności, które przeżywa i wysiłek najbliższych, by im zapobiegać. Tak postępuje Augustyn wobec swej matki, który nie tylko znajduje słowa pociechy, by nie przerażała się zbytnio gąszczem różnych, na przykład, wiadomości, ale także, zwłaszcza w obliczu cierpienia, które również zauważa ${ }^{91}$, opiekuje się matką ${ }^{92}$ dając w ten sposób wyraz troski o jej zdrowie ${ }^{93}$.

Dziecko kochające matkę broni również jej dobrego imienia. Potwierdza to postawa Augustyna w polemice z Julianem, który atakował jego matkę przypominając o jej skłonności w okresie dzieciństwa do alkoholu. Augustyn staje w obronie swej matki, która, jak czytamy, w niczym Julianowi nie zaszkodziła i niczego przeciw niemu nie powiedziała. On zaś, zwyciężony pożądliwością złorzeczenia, swą wypowiedzią pragnie obrazić jego matkę. W kontekście tej wypowiedzi Biskup Hippony gratuluje rodzicom adwersarza tego, że umarli wcześniej, zanim zobaczyli go jako heretyka ${ }^{94}$.

Biskup Hippony jest też przekonany, że w sytuacji gdy mamy do czynienia z wyrodnym synem, sam Bóg staje w obronie jego matki ${ }^{95}$. Syn, który kocha swą matkę, pragnie również dla niej szczęścia. Zauważa to Augustyn na przykładzie postępowania Scypiona Nazyki, najszlachetniejszego, jego zdaniem, człowieka, który pragnąc tej wartości dla swej matki zgodziłby się nawet, by ją w dowód zasług dla państwa, ogłoszono boginią ${ }^{96}$.

c). Rozmowa z matką. Analizując wypowiedzi Biskupa Hippony wskazujące na pozytywne zachowania dziecka wobec matki musimy stwierdzić, iz ich

${ }^{88}$ Por. Epistola 212, PL 33, 965.

${ }^{89}$ Por. Epistola 243, 12, PL 33, 1059: „Si quid sane pecuniae res tua familiaris habet, cujus te implicari negotio nec oportet nec decet, revera tribuendum est matri et domesticis tuis".

${ }^{90}$ Podkreśla to na przykład J. Jundziłł (Ideat żony i matki, s. 822) oraz G. Bardy (Święty Augustyn, s. 102).

91 Por. Bardy, Swięty Augustyn, s. 119.

92 Por. Confessiones IX 12, 30, PL 32, 776.

${ }^{93}$ Por. tamże IX 11, 28, PL 32, 776.

94 Por. Opus imperfectum contra secundam responsionem Juliani I 68, PL 45, 1090: „, [...] eisque gratulor quod ante defuncti sunt, quam haereticum te viderent".

95 Por. Epistola 34, 4, PL 33, 133.

${ }^{96}$ Por. De civitate Dei II 5, PL 41, 51. Publius Cornelius Scipio Nasica Corculum był konsulem w r. 162, a zmarł w 147 przed Chrystusem. Jest autorem listu autobiograficznego, prawdopodobnie do króla Masynissy. Ten list wykorzystał Plutarch do opisu bitwy pod Pydną (168 r. przed Chr.) w biografii Emiliusa Paulusa, zob. Mała Encyklopedia Kultury Antycznej, Warszawa 1983, s. 666. 
autor nie tylko mówił o swej matce, jak zauważa to $\mathrm{H}$. Chadwick ${ }^{97}$, językiem wzniosłym, nacechowanym wdzięczną miłością czy, według G. Bardy’ego, niezrównaną czułością ${ }^{98}$, ale także często, co podkreśla S. Abt, rozmawiał ze swą matką ${ }^{99}$, która była dla niego wiernym przyjacielem ${ }^{100}$. Ten dialog, zwłaszcza o przemijalności rzeczy ziemskich wraz ich pięknem i chwałą, w przeciwieństwie do wiecznej mądrości Boga, sprawiał wrażenie, że wydawało się, iż rozmowa ta wciągała ich oboje, zdaniem $\mathrm{H}$. Chadwicka, w jakiś ponadczasowy świat ${ }^{101}$.

Lektura pism Augustyna pozwala również zauważyć, że te rozmowy prowadzone były w atmosferze szczerości nie tylko po nawróceniu ich autora, gdy, jak czytamy, zaraz udał się do swej matki i opowiedział, jak to się stało ${ }^{102}$, ale i przed podjęciem ostatecznej w tej materii decyzji ${ }^{103}$.

Biskup Hippony, jak to wynika z jego wypowiedzi, starał się również udzielać swej matce, zawsze w sposób bardzo delikatny, różnych objaśnieñ $^{104}$, a także rad dotyczących, na przykład, praktykowania postów ${ }^{105}$, czy też, by z uzyskanych wiadomości wybierała tylko te, o doniosłym znaczeniu ${ }^{106}$. Innymi słowy, Augustynowi w prowadzonym dialogu z matką chodziło o to, by jego matka strzegła silnie i przezornie wiary, którą zaczerpnęła z tajemnic religijnych, by ją zachowywała niezmiennie i wytrwale w postępowaniu w życiu doczesnym ${ }^{107}$.

Jak to pokazuje lektura pism naszego autora, nie ograniczał on swych rad tylko do osoby swej matki, ale, jako duszpasterz, starał się pamiętać i o innych

97 Por. H. Chadwick, Augustyn, tłum. T. Szafrański, Warszawa 2000, 103. W tym miejscu należy dodać, że choć nie zgadzamy się z poglądami W. Pałubickiego, który uważał (Kobieta w tradycji patrystycznej, „Euhemer” 3:1981, 38), że w tradycji patrystycznej pogłębił się proces degradacji społecznej kobiety, to jednak podzielamy wypowiedzianą tutaj przez niego opinię, że Augustyn cenił wysoko swą matkę.

98 Por. Bardy, Swięty Augustyn, s. 425.

99 Por. S. Abt, Święty Augustyn jako pedagog, Kraków 1930, 12; Kornatowski, Spotecznopolityczna myśl św. Augustyna, s. 48.

${ }^{100}$ Por. Chadwick, Augustyn, s. 103.

101 Por. tamże.

102 Por. Confessiones VIII 12, 30, PL 32, 762: „Inde ad matrem ingredimur, indicamus; gaudet".

103 Por. Trapè, Ś więty Augustyn, s. 72. W tym miejscu autor zaznacza, że Augustyn oświadczył swej matce, iż nie będąc chrześcijaninem katolikiem, przestał już być manichejczykiem; zob. Confessiones VI 1, 1, PL 32, 719: ,[...] non me quidem jam esse manichaeum, sed neque catholicum christianum [...]".

${ }^{104}$ Por. De ordine I 11, 32, PL 32, 993. Tutaj autor objaśnia swej matce znaczenie pojęcia filozofia.

105 Por. Epistola 54, 1-3, PL 33, 200.

106 Por. De ordine II 17, 45, PL 32, 1016.

107 Por. tamże II 17, 46, PL 32, 1016: ,[... ] admoneo te, quantum filius audeo, quantumque permittis, ut fidem istam tuam, quam venerandis mysteriis percepisti, firme cauteque custodias $[\ldots] "$. 
matkach. Przykładem tego jest jego zachęta, kierowana do matki i wdowy Julianny, która wyrzekła się drugiego małżeństwa, by wytrwać w czystości, dbając o piękno ducha, by również brać przykład z postępowania swej teściowej i z nią rozmawiać, jak walczyć z pokusą, a przede wszystkim, by ustawicznie się modlić ${ }^{108}$.

d). Szacunek. Kolejną postawą, która winna charakteryzować zachowanie dziecka wobec matki, jest okazywany jej szacunek. Autor jest bowiem zdania, że w człowieku, jak czytamy, ,istnieje jakiś szacunek do rodziców, którego nie potrafi zniszczyć nawet rozwiązłość"109. Czyniąc aluzję do zachowania aktorów, zauważa, że ci będąc w domu ,wstydziliby się wobec swych matek powtarzać plugawe słowa i gesty, jakie wykonywali przed obliczem bogini i widzów"110. Odwołując się zaś do postępowania wspomnianego już Scypiona Nazyki stwierdza, że ten:

„nie zgodziłby się jednak, by dla jego matki, gdyby ogłoszono ją boginią, odprawiano nieprzyzwoite obrzędy, nie chciał, by jego matka była jako bogini uwielbiana obrzędami i modłami, a jako matrona obrażana słowami”"111.

Odsuwał myśl, jak czytamy dalej, „by skromność nienagannie prowadzącej się niewiasty wskutek ubóstwienia przemieniła się w swe przeciwieństwo"112. Również młodzieniec, jak przekonuje Augustyn, który jeszcze nie jest żonaty, jeśli kocha cudzołożnicę, nie sprawia, by ta zamieszkiwała z jego siostrą lub matką po to, by nie czynić niesprawiedliwości czystości ludzkiej i nie obrażać godności swej krwi ${ }^{113}$.

Tę postawę wobec rodziców, jak pokazują to inne wypowiedzi, Augustyn stara się jednak głębiej umotywować opierając się przede wszystkim na nauce płynącej z Pisma św. Mówi o tym w kontekście refleksji nad obecnością Chrystusa na weselu w Kanie. Zauważa, że ten, na którego gody Chrystus przybył, dlatego pojął żonę, aby miał dzieci i pragnął, aby szanowały tę, która je zrodzi. Myśl tę Biskup Hippony kończy przypomnieniem, że Bóg nakazuje szanować rodziców ${ }^{114}$. Tę prawdę przypomina również w swej polemice z Julianem pe-

108 Por. De bono viduitatis 19, 24, PL 40, 46.

109 De civitate Dei, 2, 4, PL 41, 50, tłum. W. Kornatowski: Św. Augustyn, O państwie Boźym, I, Warszawa 1977, 137-138.

110 Tamże, Kornatowski I 138.

111 Tamże I 5, PL 41, 50, Kornatowski I 139.

112 Tamże.

113 Por. Sermo 349, 4, PL 39, 1531: „,[...] puto quia et adolescens nondum habens uxorem, si diligat meretricem, non eam facit habitare cum sorore sua, non eam facit habitare cum matre sua, ne injuriam faciat humanae pudicitiae, ne offendat decus sanguinis sui”.

${ }^{114}$ Por. In Joannis Evangelium tractatus VIII 5, PL 35, 1452: „[...] ille ergo venerat ad nuptias, ut exhonoraret matrem, cum propter filios habendos, quibus reddere honorem parentibus imperat Deus $[\ldots] "$. 
lagianinem stwierdzając, że jego rodzice, będący chrześcijanami, również zasługują na szacunek ${ }^{115}$.

Biskup Hippony, jak to wskazują jego pisma nie ogranicza się tylko do teoretycznych refleksji, ale samemu stara się dać przykład szacunku, którym obdarza swą matkę ${ }^{116}$. Ta postawa wobec matki objawia się, na przykład, w skierowanym ku niej uśmiechu ${ }^{117}$, wypowiadanych słowach pełnych szacunku i delikatności ${ }^{118}$ czego przykładem może być nazwanie jej służebnicą Pańską $^{119}$. Augustyn przyznaje też otwarcie, że otaczał swą matkę także czcią, która jednak, jak zauważa, nie może się porównywać z jej oddaniem dla niego ${ }^{120}$. W jego wypowiedziach znajdujemy także słowa usprawiedliwiające decyzję matki co do odroczenia jego chrztu ${ }^{121}$ czy też stwierdzenie, że mógłby chętnie stać się jej uczniem mając na uwadze jej stosunek do życia ${ }^{122}$.

e). Wdzięczność. Mówiąc o pozytywnych postawach dziecka wobec matki, na podstawie pism św. Augustyna, nie możemy pominąć tematu wdzięczności. Potwierdzenie tego znajdujemy w liście Biskupa Hippony do Letusa, w którym zachęca adresata, by ten starał się okazać swej matce wdzięczność odpłacając wartościami duchowymi za otrzymane cielesne, a wiecznymi za doczesne ${ }^{123}$. Również sam, jak potwierdzają to jego Confessiones, gdy pozostał po śmierci ojca na utrzymaniu matki i swego dobroczyńcy Romaniana, im obu starał się okazać wdzięczność ${ }^{124}$, o matce zaś wypowiadał się, jak zauważa to Chadwick, Z wdzięczną miłością ${ }^{125}$.

Augustyn, jak wskazuje to jedna z jego wypowiedzi, nie tylko tak wypowiadał się o matce, ale także w ten sposób do niej się zwracał dziękując za jej dar modlitwy w jego intencji, o którą prosił. Z przekonaniem więc twierdził, jak

115 Por. Opus imperfectum contra secundam responsionem Juliani I 68, PL 45, 1090: „Ego vero parentes tuos tanquam catholicos christianos honorabiles habeo [...]”. W tym miejscu pragniemy podkreślić, że nigdy nie spotkaliśmy się z pogardliwą i pozbawioną szacunku wypowiedzią Augustyna pod adresem rodziców niechrześcijańskich.

116 Por. Jundziłł, Ideat żony i matki, s. 822; Bardy, Święty Augustyn, s. 38.

117 Por. De beata vita II 16, PL 32, 967: „Arrisi matri”.

118 Por. Confessiones IX 12, 30, PL 32, 776: ,,[...] nunquam se audisse ex ore meo jaculatum in se durum aut contumeliosum sonum [...]"; zob. Jundziłł, Ideat zony i matki, s. 822.

119 Por. Confessiones IX 13, 34, PL 32, 778: ,[...] illa famula tua [...]”; zob. Bardy, Święty Augustyn, s. 120.

120 Por. Confessiones IX 12, 30, PL 32, 776: „Sed tamen quid tale, Deus meus, qui fecisti nos, quid comparabile habebat honor a me delatus illi, et servitus ab illa mihi?".

121 Por. Confessiones I 11, 18, PL 32, 669.

122 Por. De ordine I 11, 32, PL 32, 994:,,[...] egone me non libenter tibi etiam discipulum dabo $[\ldots] ? "$

123 Por. Epistola 243, 10, PL 33, 1058: ,[...] noli esse ingratus, repende gratiam matri tuae, repende spiritualia pro carnalibus, pro temporalibus sempiterna".

124 Por. Bardy, Święty Augustyn, s. 45.

125 Por. Chadwick, Augustyn, s. 103. 
to pokazane zostało już w innym kontekście, że to właśnie dzięki jej modlitwom i jej zasługom dokonał się w nim i w osobach jego przyjaciół proces nawrócenia $^{126}$. Zrozumiałym jest więc i nie budzącym wątpliwości wyznanie naszego autora, z którego wynika, że swej matce zawdzięcza on wszystko czym żyje $\mathrm{e}^{127}$.

f). Pamięć o matce. Do pozytywnych postaw dziecka wobec matki należy również utrwalanie pamięci o niej i przekazywanie swych refleksji kolejnym pokoleniom. Czynił tak Biskup Hippony, który pisząc swe Confessiones, a zwłaszcza księgę IX będącą panegirykiem ${ }^{128}$ na cześć matki gdzie poznajemy szczegółowo opisany jego stosunek do niej, jak i jej ewolucję duchową ${ }^{129}$, wyraźnie zaznaczył, że nie może nie wspomnieć w tych wyznaniach o swej matce i opisać życia tej, która urodziła go cieleśnie wydając na świat i duchowo gdy wprowadziła go, jak pisze, do światłości wiecznej ${ }^{130}$. Nie tyle, jak zaznacza, pragnie mówić o darach tej służebnicy, ale o darach Bożych, które w niej się ujawniły $^{131}$.

\section{ZACHOWANIE DZIECKA W OBLICZU ŚMIERCI MATKI}

Pisma św. Augustyna przynoszą nam również szereg informacji dotyczących zachowań dziecka w obliczu śmierci matki. Zachowane wypowiedzi Biskupa Hippony pokazują nie tylko w jaki sposób przeżywał on śmierć swej matki, ale także nie brak w nich również miejsc, w których modli się i prosi o modlitwę za swą matkę. W takiej też kolejności postaramy się pokazać przemyślenia naszego autora.

1. Przeżywanie śmierci. Czytając Confessiones Augustyna możemy się przekonać, że bardzo obszernie przekazuje on informacje o chorobie i śmierci swej matki podając także dokładną jej datę. Ta pobożna, jak pisze, i „oddana Bogu dusza, rozstała się z ciałem w dziewiątym dniu choroby, w pięćdziesiątym

126 Por. De ordine II 20, 52, PL 32, 1019: ,[...] cujus precibus indubitanter credo atque confirmo mihi istam mentem Deum dedisse, ut inveniendae veritati nihil omnino praeponam [...]"; zob. Bardy, Święty Augustyn, s. 106.

127 Por. De beata vita I 2, 6, PL 32, 962: „Erant autem, non enim vereor eos singulari benignitati tuae notos interim nominibus facere, in primis nostra mater, cujus meriti credo esse omne quod vivo [...]".

${ }^{128}$ Por. Nehring, Wstęp, s. 42.

129 Por. Chadwick, Augustyn, s. 99.

130 Por. Confessiones IX 8, 17, PL 32, 771: „Sed non praeteribo quidquid mihi anima parturit de illa famula tua, quae me parturivit; et carne, ut in hanc temporalem; et corde, ut in aeternam lucem nascerer"; zob. Trapè, Święty Augustyn, s. 115.

131 Por. Confessiones IX 8, 17, PL 32, 771: „Non ejus, sed tua dicam dona in ea; neque enim seipsam fecerat, aut educaverat seipsam". 
szóstym roku życia”, gdy on sam miał trzydzieści trzy lata ${ }^{132}$. Nasz autor przyznaje również, że to on był tym, który zamykał oczy zmarłej ${ }^{133}$, a potem, wraz z najbliższymi zorganizował jej pogrzeb ${ }^{134}$.

Wypowiedzi Augustyna, jak możemy się przekonać, nie są jednak tylko suchą informacją o śmierci i pogrzebie matki, ale przede wszystkim pokazują przeżycia dorosłego już dziecka rozstającego się z matką ${ }^{135}$. Dostrzec możemy w nich głęboką boleść i smutek ${ }^{136}$ po stracie kogoś, kogo szczerze kochał i kto w jego życiu, zwłaszcza po nawróceniu, zajmował ważne miejsce. W jego sercu pozostała bolesna rana, co potwierdzają jego Wyznania pisane na długo po jej śmierci ${ }^{137}$, która dla niego była wielkim ciosem ${ }^{138}$. Augustyn przyznaje, ze po śmierci matki najbardziej bolało go rozerwanie najsłodszej i najdroższej wspólnoty życia ${ }^{139}$. Jej śmierć była również powodem, jak pisze, utraty pociechy ${ }^{140}$, jakiej ona jemu udzielała. Czuł głębokie rozdarcie w swej duszy, a życie jego wydawało się zburzone, gdyż przedtem „było ono wzajemną wspólnotą”141. Mimo tego starał się jednak powstrzymywać, jak czytamy, „łzy i płacz rozpaczliwym wysiłkiem woli”. Przyznaje jednak, że:

„,wszystko co w nim było dziecinne wzbierało płaczem, ale bardziej dojrzały głos serca upominał go i zmuszał do spokoju"142.

Stąd też, gdy z perspektywy lat pisze swe Confessiones, przyznaje, że tylko słowami prawdy, które były balsamem, łagodził swą mękę, innym zaś wydawał się być niezdolnym do odczuwania bólu ${ }^{143}$. Augustyn wyznaje również, że:

„ganił w sobie nadmiar czułości, walczył z zalewającym go smutkiem, który nie zdołał wycisnąć z jego oczu łez, ani też zmienić wyrazu jego twarzy" ${ }^{\prime 44}$.

132 Por. tamże IX 11, 28, PL 32, 776.

133 Por. tamże IX 12, 29, PL 32, 776: „Premebam oculos ejus [...]”.

134 Por. tamże IX 12, 31-32, PL 32, 776-777.

135 Por. Jundziłł, Ideał żony i matki, s. 822.

136 Por. Confessiones IX 12, 29, PL 32, 776: „,[..]moestitudo ingens [...]”; zob. Bardy, Swięty Augustyn, s. 119.

137 Por. Bardy, Święty Augustyn, s. 120.

138 Por. Nehring, Wstęp, s. 42.

139 Por. Confessiones IX 12, 30, PL 32, 776: „Quid ergo erat quod intus mihi graviter dolebat, nisi ex consuetudine simul vivendi dulcissima et charissima repente disrupta vulnus recens?"

${ }^{140}$ Por. tamże IX 12, 30, PL 32, 776: ,, Quoniam itaque deserebar tam magno ejus solatio [...]”.

141 Tamże IX 12, 30, PL 32, 776: ,[...] et quasi dilaniabatur vita, quae una facta erat ex mea et illius", Kubiak, s. 254.

142 Tamże IX 11, 28, PL 32, 776, Kubiak, s. 252; IX 12, 29, PL 32, 776; zob. Bardy, Święty Augustyn, s. 119.

${ }^{143}$ Por. Confessiones IX 12, 31, PL 32, 776-777: ,[...] eoque fomento veritatis mitigabam cruciatum tibi notum, illis ignorantibus et intente audientibus, et sine sensu doloris me esse arbitrantibus".

144 Tamże IX 12, 31, PL 32, 777: ,[...] increpabam mollitiem affectus mei, et constringebam fluxum moeroris, cedebatque mihi paululum; rursusque impetu suo ferebatur, non usque ad 
Nie płakał też, gdy z domu wynoszono ciało zmarłej matki ${ }^{145}$ ani też podczas sprawowania obrzędów pogrzebowych ${ }^{146}$.

Czytając te refleksje naszego autora musimy na ich podstawie przyznać, że nie oznacza to jednak, ze Biskup Hippony nie płakał wcale. Potwierdza to kolejna jego wypowiedź, w której podkreśla, że gdy jego serce wyleczyło się z owej rany, która mogła świadczyć o nadmiarze ziemskiego przywiązania do matki, wylewał przed Bogiem w intencji swej matki łzy zupełnie inne, bo wypływające z duszy wstrząśniętej świadomością niebezpieczeństw, jakie zagrażają wszystkim, którzy umierają w Adamie ${ }^{147}$. Przyznał też, w innym miejscu, że „doznał pociechy gdy przed Bogiem zapłakał nad nią i nad sobą, ofiarowując te łzy w jej i swojej intencji”. Płakał, nie obawiając się już z tego powodu pogardy, z tęsknoty za matką, która, jak czytamy, ,na pewien czas umarła dla jego oczu, a przedtem przez wiele lat płakała nad nim by on się nawrócił"148.

Nie możemy się więc dziwić, że jemu samemu, jak również obecnym przy zmarłej:

„nie wydawało się, by śmierć takiej matki oblewać łzami, osnuwać skargą i lamentem gdyż w ten sposób opłakuje się śmierć uważaną za nieszczęście albo całkowite unicestwienie" ${ }^{149}$.

Nie tylko dla Augustyna, będącego już duchowo przygotowanego w świetle

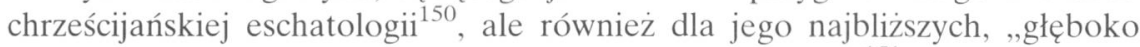
wierzących wiarą opartą na niezachwianych argumentach"151, jak przekonuje

eruptionem lacrymarum, nec usque ad vultus mutationem, sed ego sciebam quid corde premerem [...]", Kubiak, s. 256.

${ }^{145}$ Por. Confessiones IX 12, 32, PL 32, 777: „Cum ecce corpus elatum est, imus, redimus sine lacrymis".

${ }^{146}$ Por. tamże IX 12, 32, PL 32, 777: ,[...] nec in eis precibus ego flevi: sed toto die graviter in occulto moestus eram [...]".

147 Por. tamże IX 13, 34, PL 32, 778: „Ego autem, jam sanato corde ab illo vulnere in quo poterat redargui carnalis affectus, fundo tibi, Deus noster, pro illa famula tua longe aliud lacrymarum genus, quod manat de concusso spiritu consideratione periculorum omnis animae quae in Adam moritur"; zob. Bardy, Święty Augustyn, s. 120.

148 Por. Confessiones IX 12, 33, PL 32, 777-778: ,,[... libuit flere in conspectu tuo de illa et pro illa, de me et pro me. Et dimisi lacrymas quas continebam, ut effluerent quantum vellent, substernens eas cordi meo; et requievit in eis, quoniam ibi erant aures tuae, non cujusquam hominis superbe interpretantis ploratum meum. Et nunc, Domine, confiteor tibi in litteris. Legat qui volet, et interpretetur ut volet, et si peccatum invenerit, flevisse me matrem exigua parte horae, matrem oculis meis interim mortuam, quae me multos annos fleverat ut oculis tuis viverem, non irrideat; sed potius, si est grandi charitate, pro peccatis meis fleat ipse ad te Patrem omnium fratrum Christi tui".

149 Tamże IX 11, 28, PL 32, 776, Kubiak, s. 253; IX 12, 29, PL 32, 776; zob. Bardy, Święty Augustyn, s. 119.

${ }^{150}$ Por. Kowalczyk, Człowiek i Bóg w nauce św. Augustyna, s. 85.

151 Confessiones IX 12, 29, PL 32, 776: ,[...]fide non ficta, rationibusque certis tenebamus [...]", Kubiak, s. 253. 
to jego kolejna wypowiedź, ,jego matka nie umierała nieszczęśliwie, ani nie osuwała się w nicość"152 gdyż „wszyscy byli pewni jak cnotliwie żyła"153.

2. Modlitwa za zmarlą matkę. Biskup Hippony pisząc swoje Confessiones pozostawił swym duchowym spadkobiercom rodzaj testamentu, w którym zawarł pewne dyspozycje dotyczące jego zmarłej matki. Przede wszystkim życzy, by ona:

„spoczywała w pokoju z mężem, przed którym i po którym nikomu wiary nie ślubowała, jemu służyła, by jego pozyskać dla Boga"154.

To życzenie, naszym zdaniem, koresponduje z tym, które przed śmiercią wypowiedziała jego matka, która nie troszczyła się o to, by jej zwłoki, jak pisze nasz autor, „owinięto w kosztowny całun, namaszczono wonnościami, nie pragnęła nadzwyczajnego grobowca ani pochówku w ziemi ojczystej". Jej marzeniem było jedynie to, by „o niej pamiętano przed ołtarzem, przed którym dzień i noc służyła Bogu”. Wiedziała, jak pisze Augustyn, że stamtąd „udziela się świętej ofiary, przez którą zmazane są grzechy i przez którą człowiek triumfuje nad szatanem"155.

Stąd też prosi, by o jego matce, służebnicy Pańskiej, a także i o jego ojcu, a jej mężu, „przez których ciało wprowadził go Bóg w życie, pamiętano w modlitwie przy ołtarzu Pana". Augustyn pragnie również, by wspominano z „pobożnym uczuciem jego rodziców, a braci z ojcostwa Bożego w łonie Kościoła Matki, współobywateli wiekuistego Jeruzalem”. Uważa też, że te modlitwy, bardziej niz jego, przyczynią się w większym stopniu do spełnienia tej ostatniej prośby matki ${ }^{156}$. Ze swej strony, dając przykład modlitwy za matkę, dziękuje Bogu za jej dobre uczynki i prosi o przebaczenie jej grzechów oraz o to, by Bóg jej nie sądził, ale okazał miłosierdzie. Jest bowiem przekonany, że jego matka podczas swoje życia kierowała się miłosierdziem i z całego serca odpuszczała winy tym, którzy wobec niej zawinili ${ }^{157}$.

\section{$* * *$}

Analiza wypowiedzi św. Augustyna na temat relacji pomiędzy dzieckiem, a matką prowadzi nas do następujących wniosków:

1. Biskup Hippony kierował się tutaj jasno sprecyzowaną hierarchią wartości. W jego przekonaniu miłość dziecka do matki nie może przysłaniać mi-

152 Tamże: „At illa nec misere moriebatur, nec omnino moriebatur”; zob. Kowalczyk, Człowiek i Bóg w nauce św. Augustyna, s. 94.

153 Confessiones IX 12, 29, PL 32, 776: „Hoc et documentis morum ejus [...]”.

154 Tamże IX 13, 37, PL 32, 779, Kubiak, s. 258. Augustyn nie ma tu na myśli wspólnego grobowca.

155 Tamze.

156 Tamże; zob. Bardy, Święty Augustyn, s. 120.

157 Por. Confessiones IX 13, 35, PL 32, 778. 
łości do Boga: należy kochać rodziców, ale nie więcej niż Boga czy Kościół. Miłość (secundum Deum), która winna być obecna w rodzinie, powinna wszystkich ich członków prowadzić do Boga. Gdy tak się nie dzieje, mamy do czynienia ze złą miłością.

Wyznawana przez naszego autora hierarchia wartości nie może ulec zniszczeniu także w czasie prześladowań. Również tutaj miłości do bliskich nie można przedkładać nad miłość do Boga. Ta hierarchia wartości obowiązuje również tych, którzy pragną poświęcić się służbie Bożej, pomimo sprzeciwu najbliższych lub obecności trosk doczesnych. Motywacją tak rozumianej hierarchii wartości jest dla św. Augustyna nauka Chrystusa. Opierając się na tym fundamencie Biskup Hippony uczy, że uporządkowana miłość przedkłada rzeczy ważniejsze nad mniej ważne.

2. Augustyn, w pismach będących przedmiotem naszego zainteresowania, nie pomijał w swej charakterystyce matki jej cech osobowościowych. Pochwalał więc przymioty umysłu, charakteru i ducha. Jako syn oceniając swą matkę, zwraca przede wszystkim uwagę na jej cnoty: męstwa, posłuszeństwa, a zwłaszcza cnotę miłości wobec dziecka, której wyrazem były słowa pociechy, szacunek i oddanie dla dziecka, troska o jego nawrócenie, obecność przy dziecku, macierzyńska bezpośredniość, cierpliwość, pokora i skromność. Nasz autor do pozytywnych cech matki, umysłu i ducha, zalicza także umiłowanie przez nią mądrości, jej umiejętność udzielania mądrych rad synowi oraz twórczy udział w prowadzonych dyskusjach poprzez wnoszenie w nie elementu zdrowego rozsądku i pobożności chrześcijańskiej.

Analiza wypowiedzi Augustyna pozwala również zauważyć, iż ich autor pochwalał wysoką moralność swej matki, której postępowanie pobudzało innych do chwalenia Boga. Ta moralność nie tyle była owocem wiedzy, ale przede wszystkim wiary i głębokiej religijności ubogaconej czcią dla Eucharystii i modlitwą. Wiara i wynikająca z niej moralność nie może ograniczać się do prywatności, ale ma innych doprowadzić do Boga i Kościoła.

3. Lektura pism Biskupa Hippony pozwala zauważyć, iż do negatywnych postaw syna wobec matki nasz autor zalicza, między innymi, obojętność dziecka wobec jej cierpień czy doznawanych zniewag, niewdzięczność, lekceważenie upomnień, okazywanie złości, wymuszanie spełniania własnych zachcianek, grożenie matce, prześladowanie, maltretowanie, bicie, znieważanie, pragnienie zabójstwa, a także współżycie seksualne z matką.

Wypowiedzi Augustyna przynoszą również szereg przykładów pozytywnych zachowań dziecka wobec własnej rodzicielki. Wyrazem takiego postępowania jest chęć wspólnego z matką zamieszkiwania, przywiązanie, radość z jej obecności, a przede wszystkim tworzenie wspólnoty duchowej z uwzględnieniem obowiązującej hierarchii wartości. Pozytywną postawą syna jest także różnego rodzaju forma opieki, dostrzeganie trudności, które przeżywa i wysiłek by im zapobiegać, troska o zdrowie zwłaszcza w okresie choroby, obrona jej 
dobrego imienia, pragnienie dla niej szczęścia, szczera rozmowa z matką, udzielanie objaśnień i rad, szacunek w słowach i postępowaniu, wdzięczność, a także utrwalenie na piśmie wspomnień o matce.

4. Żal i ból, a nawet płacz po śmierci matki, Augustyn przezwycięża wiarą w zmartwychwstanie i życie wieczne, nie tylko dziękuje Bogu za dobro, jakim była jego matka, ale także o to prosi innych.

\section{ATTEGGIAMENTO DEL BAMBINO DI FRONTE ALLA MADRE NELLA VALUTAZIONE DI S. AGOSTINO}

(Sommario)

Articolo di S. Agostino è composto di quattro parti. Nella prima parte è stato mostrato un parere di Agostino sulla posizione della madre nella vita del uomo. Dal intervento del Vescovo d'Ippona risulta che l'amore del bambino verso la madre non può ostacolare amore verso di Dio e la Chiesa. Amore (secundum Deum), all'infuori di circostanze, dovrebbe condurre tutti membri della famiglia a Dio.

Nella seconda parte è stato avvicinato un ritratto della madre in giudizio di un bambino adulto. Agostino approva le sue virtù del intelletto, carattere e spirito. Egli richiama l'attenzione alle virtù così come: prodezza, ubbidienza, ma prima di tutto amore verso del bambino, rispetto e cura per la sua educazione nella fede, pazienza, umiltà e modestia. Un attributo positivo della madre è anche l'amore per la sapienza, la capacità di prestare dei saggi consigli al. figlio, alta moralità come frutto di fede e di profonda devozione arricchita di venerazione per Eucaristia e di preghiera.

La terza parte tratta dei diversi comportamenti del bambino verso la madre vivente. Vescovo d'Ippona considera dei sequenti atteggiamenti come una condotta negativa: indifferenza, ingratitudine, non dare importanza agli rimproveri, mostrare la propria rabbia, estorcere di fare la propria volontà, minacciare la madre, persequitare, maltrattare, picchiare, offendere, desiderare di ucciderela ed anche avere rapporti sessuali con lei. L'interventi di S. Agostino ci portano anche una serie degli esempi positivi: abitazione con madre, attaccamento a lei, la gioia per la causa della sua presenza ma prima di tutto la creazione con lei una communità spirituale considrante la vigente gerarchia di valori, protezione, la cura della sua sanità, la difesa il buon nome della madre, desidero della fielicità, sincera conversazione, dare spiegazioni e consigli, rispetto nelle parole e nella condotta, grattitudine, e anche perpetuare per scritto dei ricordi di madre.

L'ultima parte ci ha fatto mostrare un atteggiamento di un bambino adulto al cospetto della morte di madre. La tristezza e il dolore perfino un pianto dopo la morte di madre, Agostino propone superare con la fede nella risurrezione e vita eterna e con la preghiera per le intenzioni della madre defunta. Agostino non soltanto ringrazia Dio per il bene come era la sua madre, ma anche per questo invita gli altri. 